American Journal of Environmental Sciences 6 (3): 260-267, 2010

ISSN 1553-345X

(C) 2010 Science Publications

\title{
Quality of Potable Water in Kuwait
}

\author{
${ }^{1}$ Fawzia M. Al-Ruwaih, ${ }^{2}$ Jasem M. Alhumoud and ${ }^{1}$ Sara M. Al-Mutairi \\ ${ }^{1}$ Department of Earth and Environmental Sciences, Faculty of Science, \\ ${ }^{2}$ Departments of Civil Engineering, College of Engineering and Petroleum, \\ Kuwait University, P.O. Box 5969, Safat, 13060 Kuwait
}

\begin{abstract}
Problem statement: Kuwait is an arid country with limited natural water resources. As such, Kuwait produces its drinking water using the Multi-Stage-Flash method (MSF) in distillation plants to produce distilled water from sea water. The distilled water is blended with the brackish groundwater in different blending ratios, to produce drinking water, as recommended by World Health Organization (WHO). Approach: The main purposes of this study were to determine the best blending ratios in the blending plants of Kuwait to get the best quality of drinking water according to the WHO guidelines and to reveal and control the corrosivity of the produced drinking water. In order to find out the best blending ratio, samples of drinking water from the different blending plants and groundwater samples from water well fields have been collected during 2007-2008 and analyzed for the determination of basic cations and anions. Moreover, water samples collected from the main pump stations were analyzed for Langelier Index, to reveal the corossivity level of the drinking water. Results: It was found that the best blending ratio between distilled water and brackish groundwater to obtain drinking water is in the range of 7-8\% at Shuwaikh blending plant, 8-9\% at Shuaiba blending plant and $8 \%$ at Doha blending plant respectively. While the best blending ratio at Az-Zour blending lines is between 3-4\% and between $4-5 \%$ at Sabiya blending lines. Conclusion: It was found that the produced distilled water is corrosive and causing red water problem. In addition, it was found that the mean value of the Langelier Index at Shuaiba pump station is (-0.6) and the mean value of the total alkalinity is $21.4 \mathrm{mg} \mathrm{L}^{-1}$ as $\mathrm{CaCO}_{3}$, which reveals that the drinking water from Shuaiba plant is more corrosive than the drinking water from the other plants.
\end{abstract}

Key words: Blending ratio, brackish water, distilled water, fresh water

\section{INTRODUCTION}

Location of the study area: Kuwait is located at the north shore of the Arabian Gulf and lies between $28^{\circ} 30^{\prime}-30^{\circ} 30^{\prime} \mathrm{N}$ latitudes and $46^{\circ} 30^{\prime}-48^{\circ} 30^{\prime}$ E longitudes, covering an area of $18,000 \mathrm{Km}^{2}$. It is covered with sands and gravels, rising gradually from the Arabian Gulf shores towards southwest. The climate is extremely hot, dry in summer and mild to cold in winter. The rainfall is scarce and limited to the period from October to May with an average of $110 \mathrm{~mm}$ year $^{-1}$. Due to lack of surface water and scarcity of rainfall, the groundwater is the only natural resource in Kuwait. Brackish groundwater is located in the Kuwait Group and the Dammam Formation aquifers and has a salinity ranging from $3.000-10.000 \mathrm{mg} \mathrm{L}^{-1}$. The brackish groundwater is being produced from the water well fields of Sulaibiya, Shigaya, Al-Wafra, Um-Qudair and Al-Atraf areas (Fig. 1). The production of the brackish groundwater is about 121 Million Imperial Gallons per Day (MIGD), which is mainly used for irrigation, domestic purposes and blending with distilled water.

Thus, in view of the scant natural fresh water resources and the increase of population and water demand, Kuwait since founded has to look for other sources to secure potable water requirements. Therefore, Kuwait depends on seawater desalination for its fresh water supply (Al-Jaralla and Al-Fares, 2009).

Distillation plants: In the past the people of Kuwait relied on a scant number of wells to satisfy their water needs. Those wells accompanied with fresh water transported by boats from Basra, Iraq were the main source of water supply to the people. Transporting water by boats continued for some time, where in 1939 a company was established to manage the fleet of water carriers from Iraq, by constructing three reservoirs on the shore for storage.

Corresponding Author: Fawzia M. Al-Ruwaih, Department of Earth and Environmental Sciences, Faculty of Science, Kuwait University, P.O. Box 5969, Safat, 13060 Kuwait 


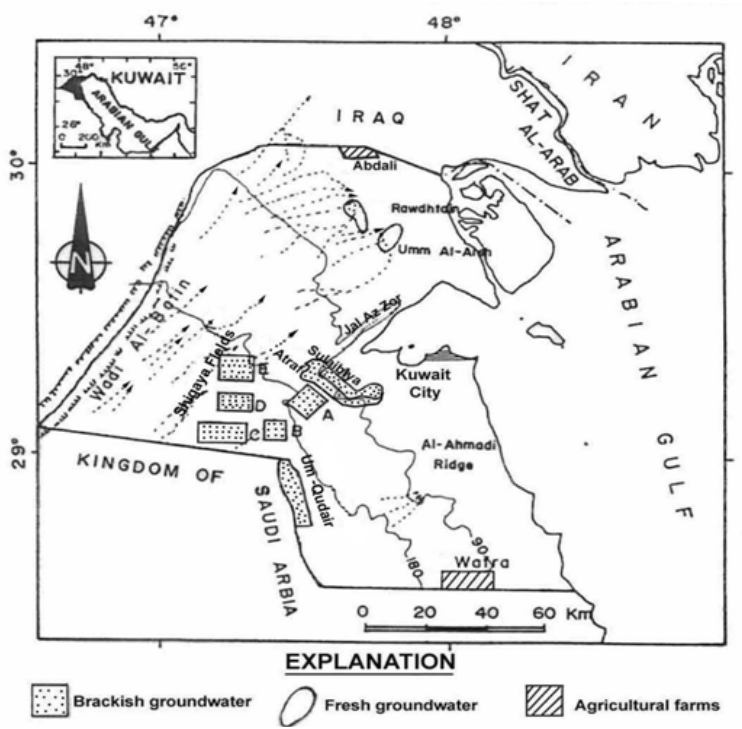

Fig. 1: Location map of the groundwater well fields in Kuwait

The first major breakthrough came in 1951 when Kuwait Oil Company (KOC) build a small sea water desalination plant with a capacity of 80.000 gallon day $^{-1}$ at the port of al-Ahmadi (Mina Al-Ahmadi) and distributed part of the water to the town of Kuwait. The first major desalination plant was built in 1953 with a capacity of 1 million gallons day ${ }^{-1}$ (mgpd). In 1978 another desalination plant was build in Doha. The capacity of the Doha plant is 42 mgpd.

The country was and is very anxious to exploit all available groundwater both freshwater for drinking and brackish water for irrigation. As for fresh groundwater it is considered a matter of prime importance. Fresh groundwater was discovered in limited quantities at both Al-Rawdhatain and Umm Al-Aish fields. Pumping operations commenced in 1962, whereas the estimated natural reserve of both fields is about 40,000 million gallons. In 1980 the Rawdhatain Water Production and Bottling Projects started to produce $1800 \mathrm{~m}^{3}$ year $^{-1}$ of mineral water. The Umm Al-Aish field is currently producing $8000 \mathrm{~m}^{3}$ year $^{-1}$ of water. Besides freshwater the country makes use of its large supply of brackish groundwater. The authority distributes this water to the consumers through separate network parallel to the freshwater network. The brackish water is intended to be used for various purposes, such as blending with distilled water, irrigation, live stock watering and construction works. It is worth mentioning that. The number of consumers connected to the fresh water network totaled 140.824 by the year 2007, while consumers connected to the brackish water network totaled 80.218 by the end of the same year (Alhumoud et al., 2003; MEW, 2008).

Currently, there are six distillation plants in Kuwait, the distillation units use the Multi Stage Flash evaporation method. Each distillation unit consists a number of stages ranging between 24-26 stages, with different unit capacities of 4.4, 7.2 and 12.5 MIGD according to each station. The Al-Zour North seawater desalination plant alone, operating since 2007, produces $567,000 \mathrm{~m}^{3} \mathrm{day}^{-1}$ of freshwater, equivalent to about $29.3 \%$ of the total production capacity. It is the fifth largest desalination plant in the world in terms of production capacity (Al-Damkhi et al., 2009). A new RO desalination plant is being built in Kuwait scheduled to begin production in 2010. The plant, worth US\$320 million, will supply drinking water for 450.000 residents in Kuwait with a capacity of $137,000 \mathrm{~m}^{3}$ day $^{-1}$ (Wangnick, 2004; Bains, 2008; Al-Damkhi et al., 2009). However, the total capacity of the distillation units in the power stations is 419.1 MIGD including High Temperature Operation (HTO) of distiller units at most of Doha West and all of Az-Zour South Station (MEW, 1994; 2008).

Drinking water production: In order to produce drinking water according to the WHO guidelines, distilled water, which is produced from the distillation plants is being mixed with the brackish groundwater produced from the water well fields. This process takes place either in the blending plants or in the blending lines operated by the Chemical Works Administration of MEW, distributed in Shuwaikh, Shuaiba, Doha, AzZour and Sabiya, where the disinfection of the produced drinking water is carried out by injecting the chlorine solution in order to kill the bacteria and the harmful organisms in water. In addition caustic soda solution is added to maintain the $\mathrm{pH}$ value of the water within the required limits according to the (WHO) guidelines for drinking water. The drinking water network starts from the blending plants' lines and passes through main reservoirs, main pump stations, main trunk lines, strategic water reservoirs sites, distribution lines, water towers, tanker filling stations and ends with consumers feeding points.

However, the drinking water gross production rose from 1.773 MIG year ${ }^{-1}$ in the late 50-119.774 MIG year $^{-1}$ in 2008, while the per capita average consumption of drinking water rose from 4,60435.912 IG year ${ }^{-1}$ in 2008 . Figure 2 and 3 represent the production and consumption of drinking water for the period 2005-2008, where the maximum production recorded was 374.641 MIGD in September 2008, while the maximum consumption recorded was 374.806 MIGD in September 2008. 


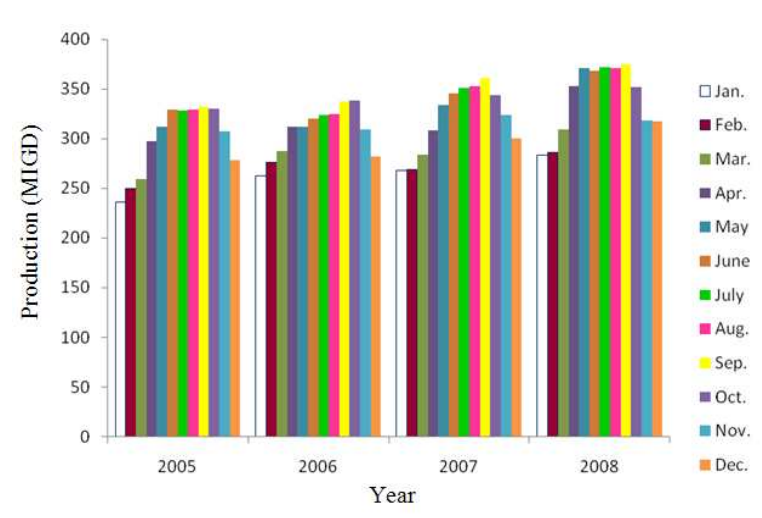

Fig. 2: Production of potable water during the period 2005-2008

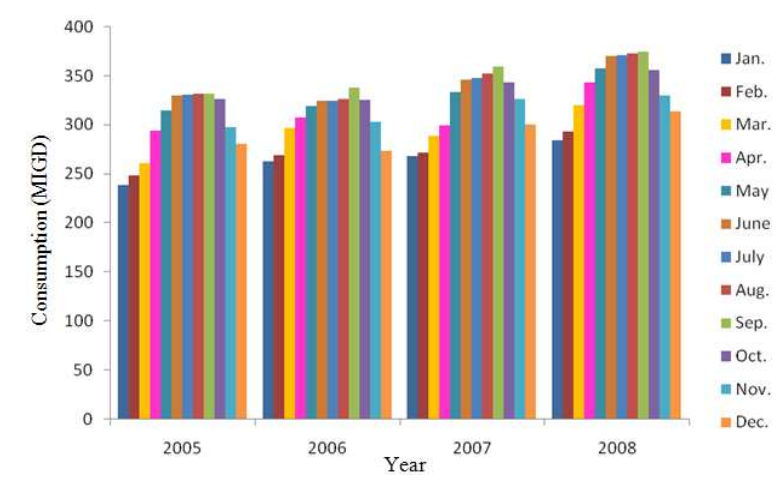

Fig. 3: The consumption of the drinking water during the period 2005-2008

Therefore, the main objectives of the study are to determine the best blending ratios between the distilled water and the brackish groundwater in the blending plants or lines to get the best quality of drinking water according to the WHO guidelines. In addition, to reveal and control the corrosivity of the produced drinking water based on the Langelier Index determination.

Water well fields and production of groundwater: The groundwater well fields which are located across the country include both operational fields and those currently under development and construction. There are 13 groundwater well fields in Kuwait located in the north, south and centre of the country. Two of the water well fields are privately owned, with the abstracted groundwater being used for irrigation of private farms. The remaining water well fields are owned by the MEW.

Furthermore, the three water well fields, Kabad, Al-Atraf and NW Um-Qudair are under construction. The greatest expected production is from Um-Qudair field at a rate of 40 MIGD. The maximum total production for all fields is estimated to be 123 MIGD. Groundwater production from the MEW well fields has been regulated since the mid $1970 \mathrm{sec}$, due to the risk of saline water intrusion (Al-Ruwaih et al., 2005).

Groundwater quality: Brackish groundwater quality varies from one field to another depending on the utilized aquifer. Table 1 displays the chemical Analysis of the brackish groundwater in Kuwait. The salinity of the groundwater ranged from 2.330$3.190 \mathrm{mg} \mathrm{L}^{-1}$ in Um-Qudair field, from 2.564$3.045 \mathrm{mg} \mathrm{L}^{-1}$ in Shigaya fields, from $3.686-4.378 \mathrm{mg}$ $\mathrm{L}^{-1}$ in Sulaibiya field, from $3.849-6.366 \mathrm{mg} \mathrm{L}^{-1}$ in AlAtraf field and from 5.066-6.180 $\mathrm{mg} \mathrm{L}^{-1}$ in Al-Wafra Field. The groundwater is of $\mathrm{Na}_{2} \mathrm{SO}_{4}$ in Um-Qudair, Shigaya and Suaibiya fields, where as $\mathrm{NaCl}$ type is dominant in Al-Atraf and Al-Wafra fields (Hadi and Al- Ruwaih, 2005; 2008).

Collection and analysis of drinking water samples: Field analysis: Field Analysis of $\mathrm{pH}, \mathrm{EC}$, temperature, residual chlorine and turbidity are usually made at the time of sampling, using portable equipments. Chlorine residual sampling is done at the consumer's faucet and at the plant. Sampling at the consumer's faucet is done to determine whether consumers are receiving water that is safe to drink.

Drinking water quality: Drinking water should be safe chemically, physically and biologically. Chlorine is the most widely used chemical for the treatment of drinking water and this process is used in Kuwait as well. Color, turbidity, taste, odor and harmful microorganisms must be absent. TDS should be $<500 \mathrm{mg} \mathrm{L}^{-1}$ (Al-Kuwait and Al-Yawm, 2001; Fredrick, 1990; AWWA, 1985) for the water to be of good quality. Water with more than $1000 \mathrm{mg} \mathrm{L}^{-1}$ of dissolved solids usually contains minerals which give it a disagreeable taste or make the water unsuitable in other respects. The palatability of drinking water has been rated by panels of tasters in relation to its TDS level as follows: Excellent, less than $300 \mathrm{mg} \mathrm{L}^{-1}$; good, between 300 and $600 \mathrm{mg} \mathrm{L}^{-1}$; fair, between 600 and $900 \mathrm{mg} \mathrm{L}^{-1}$; poor, between 900 and $1200 \mathrm{mg} \mathrm{L}^{-1}$ and unacceptable, greater than $1200 \mathrm{mg} \mathrm{L}^{-1}$. Water containing extremely most commonly used low concentrations of TDS may be unacceptable because of its flat, insipid taste. Table 2 shows the quality classification of drinking water based on TDS values according to WHO guidelines, 2006.

However, in Kuwait the groundwater produced from the water well fields is brackish, with a TDS in the range of $2.000-10.000 \mathrm{mg} \mathrm{L}^{-1}$. Therefore, the produced distilled water is pure and has low concentrations of dissolved salts, gases and a total alkalinity of less than $1 \mathrm{mg} \mathrm{L}^{-1}$ as $\mathrm{CaCO}_{3}$, which is not suitable for human use. Thus, this distilled water is blended with the brackish groundwater to produce fresh water suitable for drinking. 
Am. J. Environ. Sci., 6 (3): 260-267, 2010

Table 1: Chemical analysis of the brackish groundwater from the water well fields, $\left(\mathrm{mg} \mathrm{L}^{-1}\right)$

\begin{tabular}{|c|c|c|c|c|c|c|c|c|c|c|c|}
\hline \multirow[b]{2}{*}{ Well No. } & \multicolumn{10}{|c|}{ Um-Qudair field } & \multirow[b]{2}{*}{$\begin{array}{l}\text { Water } \\
\text { types }\end{array}$} \\
\hline & $\begin{array}{l}\mathrm{EC} \\
\left(\mu \mathrm{S} \mathrm{cm}^{-1}\right)\end{array}$ & $\mathrm{pH}$ & TDS & $\mathrm{Na}$ & $\mathrm{K}$ & $\mathrm{Ca}$ & $\mathrm{Mg}$ & $\mathrm{Cl}$ & $\mathrm{SO}_{4}$ & $\mathrm{HCO}_{3}$ & \\
\hline$\overline{2}$ & 4647 & 6.93 & 2690 & 606 & 12.36 & 390.0 & 108.0 & 897 & 1482 & 96.00 & $\mathrm{Na}_{2} \mathrm{SO}_{4}$ \\
\hline 6 & 4070 & 7.00 & 2330 & 396 & 14.17 & 374.0 & 108.0 & 542 & 1438 & 92.00 & $\mathrm{Na}_{2} \mathrm{SO}_{4}$ \\
\hline 12 & 4706 & 6.70 & 2720 & 690 & 29.00 & 433.0 & 111.0 & 951 & 1480 & 64.00 & $\mathrm{Na}_{2} \mathrm{SO}_{4}$ \\
\hline 16 & 5444 & 7.10 & 3190 & 572 & 9.68 & 480.0 & 133.0 & 1100 & 1275 & 61.00 & $\mathrm{Na}_{2} \mathrm{SO}_{4}$ \\
\hline 18 & 4370 & 7.10 & 2650 & 995 & 10.91 & 384.0 & 149.0 & 1450 & 1902 & 91.00 & $\mathrm{Na}_{2} \mathrm{SO}_{4}$ \\
\hline 22 & 4913 & 7.20 & 2850 & 697 & 9.58 & 466.0 & 112.0 & 1125 & 1563 & 62.00 & $\mathrm{Na}_{2} \mathrm{SO}_{4}$ \\
\hline 25 & 4514 & 7.04 & 2600 & 460 & 17063.00 & 400.0 & 127.0 & 659 & 1310 & 70.00 & $\mathrm{Na}_{2} \mathrm{SO}_{4}$ \\
\hline 49 & 4883 & 6.89 & 2830 & 617 & 17.00 & 435.0 & 147.0 & 1274 & 1256 & 77.00 & $\mathrm{Na}_{2} \mathrm{SO}_{4}$ \\
\hline 50 & 4897 & 6.90 & 2840 & 608 & 19.00 & 471.0 & 122.0 & 1142 & 1208 & 77.00 & $\mathrm{Na}_{2} \mathrm{SO}_{4}$ \\
\hline 53 & 4797 & 7.06 & 2770 & 605 & 17.00 & 396.0 & 113.0 & 1080 & 1104 & 89.00 & $\mathrm{Na}_{2} \mathrm{SO}_{4}$ \\
\hline \multicolumn{12}{|c|}{ Shigaya field } \\
\hline D1 & 3234 & 7.36 & 2620 & 658 & 8.62 & 245.4 & 108.4 & 406 & 1736 & 108.30 & $\mathrm{Na}_{2} \mathrm{SO}_{4}$ \\
\hline D3 & 3513 & 7.51 & 2846 & 492 & 12.30 & 282.0 & 112.4 & 480 & 1358 & 136.60 & $\mathrm{Na}_{2} \mathrm{SO}_{4}$ \\
\hline D4 & 3382 & 7.60 & 2739 & 487 & 12.33 & 269.0 & 135.0 & 345 & 1614 & 119.60 & $\mathrm{Na}_{2} \mathrm{SO}_{4}$ \\
\hline D5 & 3306 & 7.70 & 2678 & 485 & 11.40 & 269.0 & 124.0 & 291 & 1650 & 105.40 & $\mathrm{Na}_{2} \mathrm{SO}_{4}$ \\
\hline D6 & 3645 & 7.53 & 2678 & 481 & 10.02 & 271.8 & 137.0 & 540 & 1329 & 140.40 & $\mathrm{Na}_{2} \mathrm{SO}_{4}$ \\
\hline D10 & 3400 & 7.50 & 2754 & 450 & 10.14 & 271.0 & 121.7 & 450 & 1195 & 134.30 & $\mathrm{Na}_{2} \mathrm{SO}_{4}$ \\
\hline D11 & 3380 & 7.60 & 2738 & 496 & 11.84 & 266.0 & 120.0 & 325 & 1627 & 105.80 & $\mathrm{Na}_{2} \mathrm{SO}_{4}$ \\
\hline D13 & 3333 & 7.30 & 2699 & 453 & 11.44 & 295.0 & 126.0 & 450 & 1542 & 134.00 & $\mathrm{Na}_{2} \mathrm{SO}_{4}$ \\
\hline D16 & 3344 & 7.70 & 2708 & 473 & 10.36 & 297.0 & 114.0 & 421 & 1422 & 114.00 & $\mathrm{Na}_{2} \mathrm{SO}_{4}$ \\
\hline D18 & 3665 & 7.70 & 2968 & 574 & 11.28 & 271.0 & 136.0 & 505 & 1543 & 134.00 & $\mathrm{Na}_{2} \mathrm{SO}_{4}$ \\
\hline D19 & 3760 & 7.60 & 3045 & 542 & 9.98 & 297.0 & 126.0 & 528 & 1513 & 120.00 & $\mathrm{Na}_{2} \mathrm{SO}_{4}$ \\
\hline C105 & 3167 & 7.77 & 2565 & 755 & 10.97 & 277.0 & 110.0 & 662 & 1696 & 102.00 & $\mathrm{Na}_{2} \mathrm{SO}_{4}$ \\
\hline C107 & 3225 & 7.69 & 2612 & 637 & 13.13 & 277.0 & 99.0 & 367 & 1810 & 109.00 & $\mathrm{Na}_{2} \mathrm{SO}_{4}$ \\
\hline $\mathrm{C} 110$ & 3166 & 7.90 & 2564 & 605 & 11.64 & 264.0 & 124.0 & 490 & 1560 & 104.00 & $\mathrm{Na}_{2} \mathrm{SO}_{4}$ \\
\hline $\mathrm{C} 111$ & 3180 & 7.76 & 2576 & 579 & 12.03 & 280.0 & 116.0 & 518 & 1512 & 100.00 & $\mathrm{Na}_{2} \mathrm{SO}_{4}$ \\
\hline \multicolumn{12}{|c|}{ Sulaibiya field } \\
\hline 26 & 5088 & 7.41 & 4121 & 450 & 20.25 & 468 & 180 & 702 & 1508 & 127.00 & $\mathrm{Na}_{2} \mathrm{SO}_{4}$ \\
\hline 27 & 5020 & 7.50 & 4066 & 522 & 17.75 & 499 & 206 & 795 & 1960 & 122.00 & $\mathrm{Na}_{2} \mathrm{SO}_{4}$ \\
\hline 28 & 4551 & 7.50 & 3686 & 545 & 11.54 & 452 & 170 & 560 & 1779 & 129.00 & $\mathrm{Na}_{2} \mathrm{SO}_{4}$ \\
\hline 5688 & 65 & 7.00 & 4321 & 592 & 35.3 & 508 & 211 & 851 & 1988 & 91.00 & $\mathrm{Na}_{2} \mathrm{SO}_{4}$ \\
\hline 71 & 5405 & 7.10 & 4378 & 424 & 18.28 & 489 & 180 & 939 & 1405 & 126.00 & $\mathrm{Na}_{2} \mathrm{SO}_{4}$ \\
\hline 78 & 5181 & 7.00 & 4167 & 430 & 11.73 & 458 & 208 & 919 & 1368 & 118.70 & $\mathrm{Na}_{2} \mathrm{SO}_{4}$ \\
\hline 83 & 4908 & 6.90 & 3975 & 439 & 13.96 & 483 & 169 & 970 & 1503 & 119.70 & $\mathrm{Na}_{2} \mathrm{SO}_{4}$ \\
\hline 90 & 4534 & 7.19 & 3673 & 595 & 16.43 & 512 & 148 & 831 & 1650 & 137.40 & $\mathrm{Na}_{2} \mathrm{SO}_{4}$ \\
\hline 100 & 4966 & 7.40 & 4022 & 410 & 19.32 & 616 & 189 & 593 & 1969 & 149.30 & $\mathrm{Na}_{2} \mathrm{SO}_{4}$ \\
\hline \multicolumn{12}{|c|}{ Al-Atraf field } \\
\hline AT.1 & 7389 & 7.10 & 5985 & 977 & 21.30 & 621 & 204 & 1827 & 1617 & 79.52 & $\mathrm{NaCl}$ \\
\hline AT.3 & 6550 & 7.00 & 5306 & 1100 & 18.84 & 606 & 199 & 2078 & 1617 & 94.26 & $\mathrm{NaCl}$ \\
\hline AT.4 & 6776 & 7.30 & 5489 & 1250 & 19.35 & 588 & 175 & 2014 & 1693 & 89.80 & $\mathrm{NaCl}$ \\
\hline AT.5 & 6590 & 7.26 & 5337 & 875 & 19.77 & 507 & 225 & 1720 & 1594 & 89.70 & $\mathrm{NaCl}$ \\
\hline AT.6 & 7241 & 7.32 & 5865 & 810 & 17.66 & 560 & 174 & 1599 & 1503 & 84.42 & $\mathrm{NaCl}$ \\
\hline AT.7 & 7741 & 7.00 & 6366 & 940 & 26.00 & 746 & 174 & 2088 & 2579 & 84.36 & $\mathrm{Na}_{2} \mathrm{SO}_{4}$ \\
\hline AT.8 & 6099 & 7.30 & 4940 & 1050 & 19.43 & 480 & 194 & 1810 & 1653 & 108.06 & $\mathrm{NaCl}$ \\
\hline AT.9 & 6481 & 7.28 & 5249 & 910 & 20.96 & 520 & 160 & 1770 & 1583 & 103.58 & $\mathrm{NaCl}$ \\
\hline AT.10 & 7518 & 7.20 & 6089 & 988 & 21.73 & 524 & 251 & 1928 & 2028 & 71.54 & $\mathrm{Na}_{2} \mathrm{SO}_{4}$ \\
\hline AT.11 & 6040 & 7.40 & 4892 & 1208 & 16.67 & 456 & 179 & 2015 & 1789 & 115.16 & $\mathrm{NaCl}$ \\
\hline AT.12 & 5950 & 7.40 & 4819 & 1430 & 14.55 & 448 & 197 & 2211 & 1837 & 114.00 & $\mathrm{NaCl}$ \\
\hline AT.13 & 5696 & 7.30 & 4613 & 1350 & 18.20 & 480 & 145 & 2085 & 1751 & 115.96 & $\mathrm{NaCl}$ \\
\hline AT.23 & 4752 & 7.32 & 3849 & 1325 & 16.25 & 353 & 140 & 1913 & 1389 & 141.00 & $\mathrm{NaCl}$ \\
\hline AT.24 & 4882 & 7.24 & 3954 & 1250 & 14.30 & 336 & 177 & 1815 & 1662 & 119.92 & $\mathrm{NaCl}$ \\
\hline AT.25 & 6990 & 7.50 & 5032 & 859 & 16.10 & 549 & 143 & 1903 & 1312 & 112.00 & $\mathrm{NaCl}$ \\
\hline \multicolumn{12}{|c|}{ Al-WAFRA field } \\
\hline 2 & 7725 & 7.40 & 6180 & 1093 & 31.0 & 378 & 442 & 2428 & 1658 & 149.00 & $\mathrm{NaCl}$ \\
\hline 10 & 6255 & 0.04 & 5066 & 1055 & 24.0 & 315 & 382 & 2177 & 1547 & 127.60 & $\mathrm{NaCl}$ \\
\hline
\end{tabular}

Blending ratio: Distilled water is produced from six distillation plants located at Shuwaikh, Shuaiba, Doha (East and West), Az-Zour and Sabiya. In addition, there are five blending plants located at Shuwaikh, Shuaiba, Doha, Az-Zour and Sabiya, where blending of distilled water with brackish groundwater is carried out. Using 
the following mass balance equation proposed by Himmelblau and Riggs (1982).

The blending plants use a Blending Ratio (BR) calculated according to the following equation:

Blending ratio $(\%)=$

$\frac{\text { Net production of brackish water day }}{-1}=100$

Equation 1 is used to calculate the blending ratio to be used according to the production of brackish groundwater and distilled water, based on the set blending ratios (Perry and Green, 2008). Generally, at the blending plants, it is ensured that the TDS concentration of the produced drinking water does not exceed $500 \mathrm{mg} \mathrm{L}^{-1}$, as per the WHO guidelines, 2006.

Blending plants: Description of the blending plants are outlined in a report by MEW (2007), where the processes of mixing and disinfection are taking place to produce drinking water.

Table 3 summarizes the minimum, maximum and the recommended range of blending ratios at different chemical blending plants and lines in Kuwait during 2003-2008, where the produced drinking water is rated as good/excellent. As per the WHO guidelines, TDS level is as follows: Excellent, less than $300 \mathrm{mg} \mathrm{L}^{-1}$; good, 300-600 mg L ${ }^{-1}$; Fair, 600-900 $\mathrm{mg} \mathrm{L}^{-1}$; Poor, 900-1200 $\mathrm{mg} \mathrm{L}^{-1}$ and unacceptable, greater than $1200 \mathrm{mg} \mathrm{L}^{-1}$. Water with extremely low concentration of TDS may also be unacceptable because of its flat, insipid taste (WHO, 1996; 2006). It shown from the table that the best blending ratio in Shuwaikh plant ranged between 7 and $8 \%$, Shuaiba blending plant is $8 \%$, Doha blending plant, where the $8 \%$, Az-Zour blending lines ranged between 3 and $4 \%$ and Sabiya blending lines ranged between 4 and $5 \%$ to obtain TDS less than $300 \mathrm{mg} \mathrm{L}^{-1}$.

In addition it is clear from Table 3 that the blending plants at Shuwaikh, Shuaiba and Doha which receive almost similar qualities of brackish groundwater, the recommended blending ratios are almost the same, even though they are received brackish groundwater from different groundwater fields (Sulaibiya, Shigaya and Um-Gudair). While in the other blending lines at Az-Zour and Sabiya, which receive another qualities of brackish groundwater from Al-
Wafra and Al-Atraf fields have a similar recommended blending ratios.

The recarbonation process: The produced distilled water has very low concentration of dissolved salts, gases and total alkalinity as $\mathrm{CaCO}_{3}$ is $<1 \mathrm{mg} \mathrm{L}^{-1}$ and not suitable for drinking. The high purity renders the water to be chemically very aggressive towards nearly all components in the water distribution system, resulting in very severe corrosion problems. One of the by-products of this chemical attack is ferric hydroxide, a red-brown rust, which results in what is called "red water" in Kuwait (Al-Rqobah and Al-Munayis, 1989). Reddish or red-brown stains are usually associated with iron in the water. Iron types found in water are: Oxidized, soluble, colloidal, bacteria and organicbound. Each of these types presents a potential problem. As little as $0.3 \mathrm{ppm}$ in a water supply can cause staining of clothes and fixtures. The problem of the red-brown rust still exists in Kuwait since the water the sources of the fresh water are still the same (sea water from the Gulf).

The corrosion control in the distribution system involves two approaches; material selection and pacification treatment. Pacification treatment to control water quality for corrosion is limited to certain kinds and quantity of chemicals, since great volume of water must be supplied at low cost without any effect on taste, odor, color, turbidity and toxidity. These chemicals are basically used to adjust the $\mathrm{pH}$, to form precipitates by using inhibitors and to form carbonate coating. Thus, to achieve the corrosion inhibition of iron pipes, the recarbonation process was applied for the treatment of the distillate produced by the multistage flash evaporators in the plants in Kuwait (WRDC, 1999).

\begin{tabular}{ll} 
Table 2: Quality classification of drinking water, & $(\mathrm{WHO}, 2006)$ \\
\hline Water class & TDS $\left(\mathrm{mg} \mathrm{L}^{-1}\right)$ \\
\hline Excellent & $<300$ \\
Good & $300-600$ \\
Fair & $600-900$ \\
Poor & $900-1200$ \\
Unacceptable & $>1200$ \\
\hline
\end{tabular}

Table 3: Summary of the blending ratios and the recommended blending ratios at the blending plants and lines in Kuwait, 2003-2008

\begin{tabular}{|c|c|c|c|c|c|}
\hline Site & Min. BR (\%) & Max. BR (\%) & $\begin{array}{l}\text { Recommended } \\
\text { blending ratio }(\%)\end{array}$ & $\begin{array}{l}\text { TDS }\left(\mathrm{mg} \mathrm{L}^{-1}\right) \text { at the } \\
\text { Recommended blending ratio }\end{array}$ & Remarks \\
\hline Shuwaikh & 6.1 & 13.7 & $7-8$ & $274-300$ & Excellent \\
\hline Shuaiba & 2.3 & 14.1 & 8- 9 & $267-300$ & Excellent \\
\hline Doha & 2.9 & 15.0 & 8 & 298 & Excellent \\
\hline Az-Zour & 1.7 & 6.4 & $3-4$ & $186-248$ & Excellent \\
\hline Sabiya & 2.0 & 9.0 & $4-5$ & 226-282 & Excellent \\
\hline
\end{tabular}


Table 4: Summary of the Langelier Index of the main pump stations 2008

\begin{tabular}{llllll}
\hline L.I & Shuwaikh & Shuaiba & Doha & Az-Zour & Sabiya \\
\hline Min. & -0.03 & -0.12 & -0.04 & -0.03 & -0.01 \\
Max. & -0.62 & -1.08 & -0.36 & -0.62 & -0.59 \\
Mean. & -0.335 & -0.60 & -0.16 & -0.325 & -0.29 \\
\hline
\end{tabular}

Table 5: Summary of the mean values of the total alkalinity of the main pump stations during 2008

\begin{tabular}{lll}
\hline Pump station & $\begin{array}{l}\text { Mean values of } \\
\text { T. Alk. }\left(\mathrm{m} \mathrm{L} \mathrm{L}^{-1}\right)\end{array}$ & $\begin{array}{l}\text { Recarbonation } \\
\text { process }\end{array}$ \\
\hline Shuwaikh & 45.91 & Applied \\
Shuaiba & 21.40 & Not applied \\
Doha & 38.10 & Applied \\
Az-Zour & 28.82 & Applied \\
Sabiya & 53.78 & Applied \\
\hline
\end{tabular}

Distilled water from MSF distillation plants is acidified in an absorption tower using $\mathrm{CO}_{2}$ gas. The acidified water is then augmented by bicarbonate ions using $\mathrm{CaCO}_{3}$ in a number of limestone dissolution filters.

The excess $\mathrm{CO}_{2}$ presents in the recarbonated water leaving the limestone dissolution filters is degasified in a stripping tower using air. The degasifier is a packed counter flow type stripping tower. At the bottom of the tower, air is distributed to remove the $\mathrm{CO}_{2}$ gas. Finally, $15 \mathrm{wt} \%$ solution of caustic soda is dosed into the water stream for the final adjustment of $\mathrm{pH}$ value to about 8.0. It can be observed that this recarbonation process resembles the natural carbonation process taking place in aquatic system.

The recarbonated water leaving the limestone dissolution filters contains some excess of $\mathrm{CO}_{2}$ and very little dissolved oxygen and is therefore fed to a stripping tower. By direct counter current contact with air, more oxygen can be dissolved and the $\mathrm{pH}$ value can be slightly controlled by the flow rate of air. The stripping tower is packed with the same material as the absorption tower and is designed with a diameter of $2.6 \mathrm{~m}$ and a height of about $7.7 \mathrm{~m}$ respectively.

Calculation of langelier index: Several methods can be used to determine the calcium carbonate stability of water. A common method is the Langelier Index. This index is equal to the measured $\mathrm{pH}$ (of the water)-the $\mathrm{pH}$ (saturation). The $\mathrm{pH}_{\mathrm{s}}$ is a theoretical value in which calcium carbonate will neither be dissolved into nor precipitated from water. Therefore, if $\mathrm{pH}-\mathrm{pH}_{\mathrm{s}}=0$, the water is in equilibrium and will neither dissolve nor deposit calcium carbonate on the pipes. If $\mathrm{pH}-\mathrm{pH}_{\mathrm{s}}>0$ (positive value), the water is not in equilibrium and will deposit calcium carbonate on the surface of mains and other fixtures. If $\mathrm{pH}-\mathrm{pH}_{\mathrm{s}}<0$ (negative value), the water is not in equilibrium and will dissolve the calcium carbonate it contacts. No coating will be deposited on the distribution pipes. However, if the pipes are not protected, they may be corroded (AWWA, 1985). To calculate the Langelier saturation index, the following expression can be used (WRDC, 1999):

$$
\text { S.I. }=\mathrm{pH}(\text { actual })-\mathrm{pH}_{\mathrm{S}}
$$

and

$$
\mathrm{pH}_{\mathrm{S}}=\mathrm{A}+\mathrm{B}-\log \left(\mathrm{Ca}^{2+}\right)-\log (\mathrm{Alk} .)
$$

Where:

$\mathrm{A}=\mathrm{A}$ constant, based on the temperature

$\mathrm{B}=\mathrm{A}$ constant, based on the TDS of water

$\mathrm{Ca}^{2+}=$ Calcium ion concentration $\left(\mathrm{mg} \mathrm{L}^{-1}\right.$ as $\left.\mathrm{CaCO}_{3}\right)$

Alk. = Alkalinity $\left(\mathrm{mg} \mathrm{L}^{-1}\right.$ as $\left.\mathrm{CaCO}_{3}\right)$

The negative value of the Langelier Index indicates the corrosivity of the water, while the positive value shows that the water is a scale forming.

The calculations of the Langelier Index (based on the Eq. 2) of the water samples collected from the main pump stations of Shuwaikh Shuaiba, Doha, Az-Zour and Sabiya for the year 2008 were carried out and displayed in Table 4.

The fluctuation in the Langelier Index values depends on the variation of the total Alkalinity dosage in the distilled water, as it's presented in Table 5. Moreover, the Langelier Index values indicate the importance of the application of the recarbonation process, in order to reduce the corrosivity of the drinking water in the network. However, it is noticed that Shuaiba drinking water is more corrosive (the mean value of the Langelier Index is-0.6), than the drinking water in the other pump stations (Shuwaikh, Doha, AzZour and Sabiya).This is due to the fact that the recarbonation process has not yet been applied in the Shuaiba distillation Plant.

\section{CONCLUSION}

Kuwait produces its drinking water using the Multi-Stage-Flash Method (MSF) in distillation plants to produced distilled water from sea water. The distilled water produced is blended with the brackish groundwater, in order to produce drinking water in accordance with the World Health Organization (WHO) guidelines. The mixing operation takes place in the blending plants or blending lines to get the best quality of drinking water. Based on the data collected during 2003-2008 from the MEW, the range of the blending ratios was from $6.1-13.7 \%$ in Shuwaikh blending plant. From $2.3-14.1 \%$ in Shuaiba blending plant. From 2.9- 
$15 \%$ in Doha blending plant. From $1.7-6.4 \%$ in AzZour blending lines. And from 4-5\% in Sabiya blending lines. This information indicates that the produced drinking water in Kuwait is rated as an excellent/good according to the WHO guidelines.

Accordingly, to obtain an excellent quality of the drinking water, where the TDS $<300 \mathrm{mg} \mathrm{L}^{-1}$, water samples from all the blending plants and lines at different blending ratios have been collected and analyzed for 18 months during 2007-2008. It is found that the best blending ratio for Shuwaikh is between 7 and $8 \%$, for Shuaiba is between 8 and $9 \%$, for Doha is $8 \%$, for Az-Zour is from $3-4 \%$ and for Sabiya is between 4 and $5 \%$ respectively.

In Kuwait, the produced distilled water is proved to be corrosive and causing red water problem. The recarbonation plant was established in 1987 and designed to yield recarbonated water with a total alkalinity of $60-80 \mathrm{mg} \mathrm{L}^{-1}$ as $\mathrm{CaCO}_{3}$. Accordingly water samples collected from the main pump stations to calculate the Langelier Index, to reveal the corossivity of the drinking water.

It is found from the Langelier Index values, that all the drinking water is slightly corrosive, in which the range of the mean values of the total alkalinity is from 21.4-53.78 $\mathrm{mg} \mathrm{L}^{-1}$ as $\mathrm{CaCO}_{3}$, where the designed total alkalinity was recommended to be from $60-80 \mathrm{mg} \mathrm{L}^{-1}$ as $\mathrm{CaCO}_{3}$. Also, it is found that the mean value of the Langelier Index at Shuaiba pump station is (-0.6) and the mean value of the total alkalinity is $21.4 \mathrm{mg} \mathrm{L}^{-1}$ as $\mathrm{CaCO}_{3}$, which reveals that the Shuaiba drinking water is more corrosive than the drinking water in the other pump stations. This is due to the fact that the recarbonation process has not yet been applied in the Shuaiba distillation plant. Also it indicates the importance of the application of the recarbonation process to reduce corrosivity of the drinking water in the distribution networks.

Recommendations: One of the major factors for an excellent operation and improving the quality of the drinking water in Kuwait is to control the blending ratios between the distilled water and the brackish groundwater. Therefore, the following recommendations should be taken into consideration:

- To apply the best blending ratios which were determined in the blending plants or lines during this study. In Shuwaikh the blending ratio is from $7-8 \%$, from $8-9 \%$ at Shuaiba and $8 \%$ at Doha respectively. Whereas the best blending ratio at Az-Zour is between $3 \%$ and $4 \%$ and in the range of $4-5 \%$ at Sabiya
- The bicarbonate content in the distilled water should be increased to prevent the corrossivity of the produced drinking water

- The total alkalinity as $\mathrm{CaCO}_{3}$ should be in the range of $60-80 \mathrm{mg} \mathrm{L}^{-1}$, as a designed value

- The recarbonation process should be applied in Shuaiba distillation plant and all new distillation projects in Shuaiba north, Az-Zour north and Sabiya plants. In order to prevent the accumulation of red oxides (red water) in the drinking water system

- The static mixers should be used in the blending plants of Shuwaikh and Shuaiba respectively, to obtain a chemically homogeneous product, and to control the produced drinking water quality to the desired values and smooth operation

\section{ACKNOWLEDGEMENT}

The researcher would like to thank the Ministry of Electricity and Water (MEW) for their help and support. In addition, the authors would like to thank in particular Mr. Mohammed Al-Qallaf (Manager of Chemical Works Administration at MEW) for his continuous guidance and advice. In addition the authors would like to thank the distinguished reviewers of the journal for their useful comments and suggestions.

\section{REFERENCES}

Al-Damkhi, A.M., R.A. Al-Fares, K.A. Al-Khalfa and S.A. Abdul-Wahab, 2009. Water issues in Kuwait: A future sustainable vision. Int. J. Environ. Stud., 66: 619-636.

Alhumoud, J.M., H.S. Behbehani and T.H. Abdullah, 2003. Wastewater reuse practices in Kuwait. Environmentalist, 23: 117-126.

AL-Jaralla, R. and R. Al-Fares, 2009. Quality of stormwater runoff in the state of Kuwait, Al-Asema governorate. Int. J. Environ. Stud., 66: 227-239.

Al-Kuwait and Al-Yawm, 2001. Monthly Journal. 533rd Edn., Kuwait, pp: 330-331.

Al-Rqobah, H.E. and A. Al-Munayis, 1989. A recarbonation process for treatment of distilled water produced by MSF plants in Kuwait. Desalinat. J., 295-312.

Al-Ruwaih, F.M., L. Talebi and K.M. Hadi, 2005 Major geochemical processes in the evolution of Eocene carbonate aquifer, Kuwait. J. Sci. Eng., 32: 119-144.

AWWA., 1985. American Water Works Association. Water Quality Anal., 4: 147.

Bains, E., 2008. Doosan in for $\$ 320$ million Kuwait job. http://www.arabianbusiness.com/514708-doosanin-for-320mn-kuwait-job 
Fredrick, W.P., 1990. Water Quality and Treatment. 6th Edn., American Water Works Association, USA.

Hadi, K.M. and F.M. Al-Ruwaih, 2008. Geochemical evolution of fresh groundwater in Kuwait desert. Emirat. J. Eng. Res., 13: 1-9.

Hadi, K.M. and F.M. Al-Ruwaih, 2005. Impact of the environmental deposition on water quality of the limestone aquifer, Kuwait Emirat. J. Eng. Res., 10: 37-49.

Himmelblau, D.M. and J.B. Riggs, 1982. Basic Principles and Calculations in Chemical Engineering. 4th Edn., Prentice-Hall Inc., New Jersey, USA., pp: 415.

MEW., 1994. Doha West/Az-Zour South ecarbonation Project, Kuwait. A Report Prepared by Ansaldo Industries for MEW, pp: 155.

MEW., 2007. Study, design and Development of Kuwait. Water Distribution Scheme, Vol. 4, Ministry of Electricity and Water, Kuwait.
MEW, 2008. Statistical Yearbook (Water). 33rd Edn., Ministry of Electricity and Water, Kuwait.

Perry, R.H. and D.W. Green, 2008 Perry's Chemical Engineers' Hand Book. 8th Edition, McGraw-Hill, New York, USA.

Wangnick, G.W.I., 2004. Worldwide Desalting Plants Inventory. Global Water Intelligence, Pacific Institute, Oxford, England.

WRDC., 1999. The Change of Water Quality After Finishing Recarbonation Project at Doha West AzZour Desalination Plants. Water Resources Development Centre, MEW, Kuwait.

WHO., 1996. Guidelines for Drinking Water Quality. 2nd Edn., World Health Organization, Geneva, pp: 951.

WHO, 2006. Guidelines for Drinking Water Quality. 3rd Edn., Vol. 1, World Health Organization, USA. 